\title{
Integrated Furnace for Combustion/Gasification of Biomass Fuel for Tobacco Curing
}

\author{
Jian-an Wang ${ }^{1,2} \cdot$ Qian Zhang $^{2} \cdot$ Yue-wei Wei $^{2} \cdot$ Gai-he Yang $^{1} \cdot$ Feng-jie Wei $^{3}$
}

Received: 29 July 2017 / Accepted: 18 January 2018 / Published online: 27 January 2018

(c) The Author(s) 2018. This article is an open access publication

\begin{abstract}
A new system for providing heat for the flue-curing of tobacco was developed by modifying the conventional direct combustion of biomass fuel (bio-fuel) such that the energy stored in the fuels was fully utilized. The system consisted of an integrated furnace with a heat dissipation structure for combusting and gasifying bio-fuel including solid fuel as well as combusting the generated gas, and a heat exchanger with a special flue pipe layout. The new device was tested through experiments in different tobacco-growing areas, using the controlled direct combustion of coal and biomass fuel for flue-curing in a bulk curing barn. The results showed that the distribution of temperature in the longitudinal section of the new system exhibited a regular temperature transition pattern corresponding to the solid fuel and gas combustion areas. The amount of carbon monoxide in the flue gas at the chimney exit indicated that the burning of the biomass briquette fuel was more complete, with less than $1.7 \%$ carbon monoxide generated. The thermal efficiencies of the biomass briquette fuel and firewood were 55.26 and $53.17 \%$, respectively, which were higher than that of coal $(49.52 \%)$. The newly developed integrated furnace would be well suited for tobacco curing in tobacco-growing areas, and could be used commercially for drying agricultural products on different scales.
\end{abstract}

Keywords Bio-fuel $\cdot$ Secondary combustion furnace $\cdot$ Heat exchanger $\cdot$ Drying device

\section{Introduction}

The flue-curing of tobacco leaves is an energy-intensive process, for which coal has conventionally been used as the primary fuel in China [1]. About 4 million tons of coal are used to cure tobacco every year [2]. In recent years, with the frequent occurrence of smog in northern China, air pollution caused by tobacco curing using coal-fired heating has attracted significant attention [3]. The government is therefore encouraging the use of clean energy to develop a lowcarbon economy and green industries, to which the tobacco industry has actively responded [4].

Gai-he Yang

gaiheyang1957@163.com

1 College of Agronomy, Northwest A\&F University, Yangling 712100, Shaanxi, China

2 College of Tobacco Science, Henan Agricultural University, Zhengzhou 450002, China

3 Henan Provincial Tobacco Company, Zhengzhou 450008, China
The primary biomass fuels used as a clean source of curing energy for the flue-curing of tobacco are biomass briquette fuel (BBF) and firewood [5, 6]. In China, many manufacturers are subsidized by local governments to encourage them to utilize agricultural and forestry waste to produce $\mathrm{BBF}$, which is also being gradually adopted for industrial power generation and residential heating [7, 8]. Several researchers have investigated the use of BBF as a heat source for heating supply, as an alternative to coal $[9,10]$. Typically, BBF is used in a furnace originally designed to burn coal, to provide the heat needed for the tobacco curing [11, 12]. However, the direct combustion of bio-fuels in this way is very inefficient $[13,14]$. Given that the BBF has a lower density than coal [15] and requires careful management of the fan-assisted intake of combustion air, the use of a conventional coal-fired furnace usually incurs frequent refuelling during the tobacco curing process, which increases the associated labor costs. Xiang et al. [16] modified direct-fired BBF heating by incorporating pyrolysis and gasification curing equipment, achieving a high fuel-utilization rate and accurate control of the curing dry-bulb temperature (DBT). Furthermore, several 
researchers have been working on the development of BBF equipment aimed specifically at tobacco curing. Typically, the gas produced by a gasification process is transported through pipes, connected in parallel between multiple bulk curing barns, to the furnace of the heating chamber, to realize biomass gasification gas heating [17]. However, owing to the size of tobacco plants and BBF engineering equipment prices at that time, the devices were not widely adopted for tobacco curing. The use of firewood for tobacco curing has a very low energy efficiency and is therefore used only by a few tobacco planters in remote mountainous areas. In this case, the direct combustion mode is similar to that reported in a previous study [18].

The furnace and heat exchanger are the two primary parts of the heating system used for tobacco curing [13]. The heat exchanger, which consists of several flue pipes, dissipates the heat generated by the burning of the fuel and is directly connected to the furnace. Typically, a conventional flue pipe layout is parallel to the ground $[19,20]$, to produce an upward flow of hot air. This layout is not, however, conducive to heat dissipation given the length of time that the hot gas is present in the flue pipes.

Based on previously developed furnace designs, as well as the principles and heat requirements of tobacco curing, the present study set out to create a preliminary design which was then used to conduct experiments to develop an dedicated integrated furnace that is tailored to curing flue-cured tobacco, relative to conventional furnaces, and which completely utilizes the thermal energy stored in bio-fuels.

\section{Materials and Methods}

\section{Biomass Fuel Combustion System}

\section{Energy Exchange}

In China, the basic design and specifications of bulk curing barns with coal-fired heating with either descending or rising air were established by the State Tobacco Monopoly Administration in 2009 (Fig. 1) [21]. At present, there are 830,000 bulk curing barns in China's tobacco-growing areas, more than $95 \%$ of which use coal-fired heating. Given the general standard for the amount of fresh leaves that can be loaded into a bulk curing barn (5000 kg/batch), any new integrated furnace design must be capable of producing sufficient heat to cure this amount of tobacco.

The maximum heat required by the system per hour per batch in per bulk curing barn is given by Eq. (1).

$\mathrm{Q}_{1}=\frac{m_{1} \cdot \alpha \cdot \mathrm{C}_{\mathrm{w}} \cdot \beta}{\eta}$

where $\mathrm{Q}_{1}(\mathrm{~kJ} / \mathrm{h})$ is the maximum heat required by the system per hour per batch in per barn and $m_{1}(\mathrm{~kg})$ is the weight of the leaves per batch per barn. Furthermore, $\alpha(\%)$ is the percentage of water lost by the fresh green leaves as they are cured, which approaches $83 \%$ because fresh leaves lose $85-90 \%$ of their water after they are cured, in addition to $5 \%$ water loss while they are hung in racks and loaded into curing barns. Then, $\mathrm{c}_{\mathrm{w}}\left(2.6 \times 10^{3} \mathrm{~kJ} / \mathrm{kg}\right)$ is the average heat
Fig. 1 Conventional layout of bulk curing barn with descending air

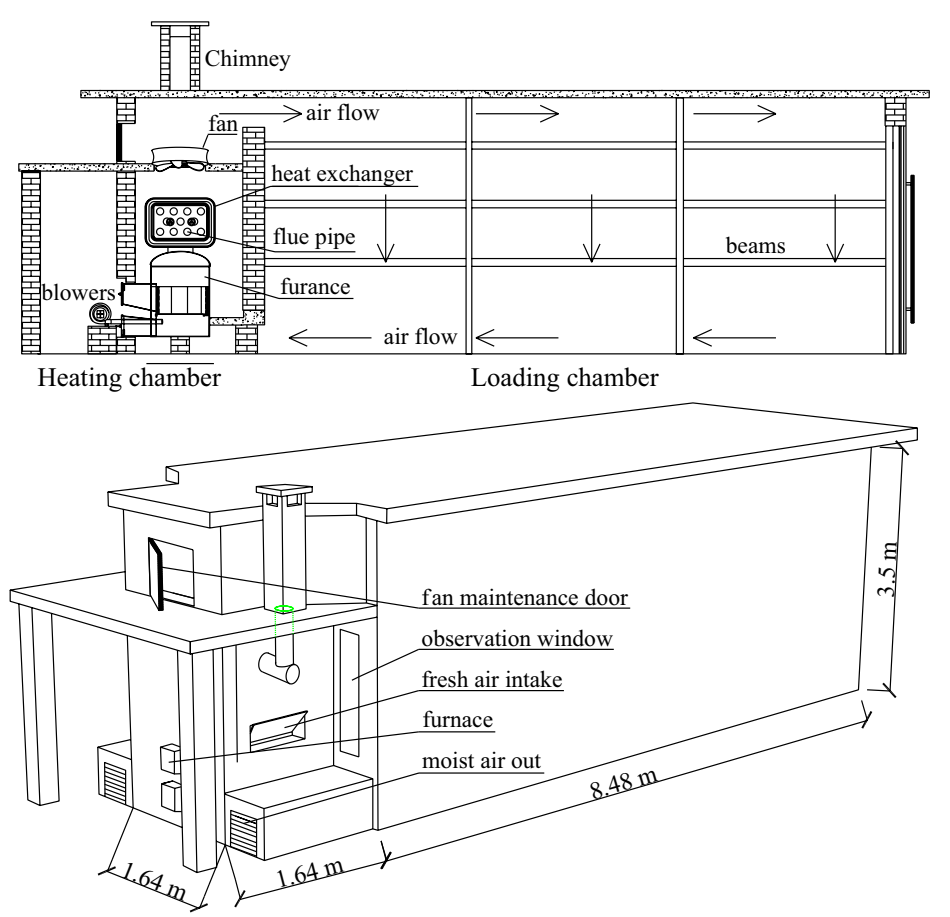


of vaporization for a leaf during the normal curing process [3], and $\beta(\%)$ is the maximum percentage of tobacco water loss per hour per batch in per barn during curing.

$\mathrm{V}_{\mathrm{L}}\left(\mathrm{m}^{3}\right)$ is the furnace volume, calculated using Eq. (2).

$\mathrm{V}_{\mathrm{L}}=\frac{Q_{1}}{R_{L}}$

where $R_{L}(\mathrm{~kJ} / \mathrm{h})$ is the visible volumetric heat loading in the furnace. This is also called the furnace strength of the combustion chamber, the value of which is $1.046 \times 10^{6}$ $-1.463 \times 10^{6} \mathrm{~kJ} / \mathrm{m}^{3} \mathrm{~h} \mathrm{[22]}$.

$\mathrm{F}_{\mathrm{J}}\left(\mathrm{m}^{2}\right)$ is the furnace grate area, calculated using Eq. (3).

$\mathrm{F}_{\mathrm{J}}=\frac{Q_{1}}{R}$

where $\mathrm{R}$ is the furnace cross-sectional heat release rate, the value of which is $3.5 \times 10^{5}-8.5 \times 10^{5} \mathrm{~kJ} / \mathrm{m}^{2} \mathrm{~h}$ [22].

$\mathrm{F}_{\mathrm{g}}\left(\mathrm{m}^{2}\right)$ is the heat dissipation area of the flue pipe, calculated using Eq. (4).

$\mathrm{F}_{\mathrm{g}}=\frac{Q_{1}}{k_{g} \cdot \mathrm{t}}$

where $\mathrm{k}_{\mathrm{g}}\left(\mathrm{kJ} /\left(\mathrm{m}^{2} \mathrm{~h}{ }^{\circ} \mathrm{C}\right)\right)$ is the heat dissipation coefficient of the flue pipe material (of a given thickness), $\mathrm{t}\left({ }^{\circ} \mathrm{C}\right)$ is the average temperature of the gas in the flue pipe, which is an empirical value. According to the measurements obtained for coal in actual production, the temperature at the furnace exit is $860-1000^{\circ} \mathrm{C}$, while at the entrance to the chimney it $230-260{ }^{\circ} \mathrm{C}$, so a suitable value for it is $510-680^{\circ} \mathrm{C}$.

Next, $\eta(\%)$ is the system efficiency of the bulk curing barn, which is calculated using Eq. (5).

$\eta=\frac{\left(m_{1}-m_{2}\right) \cdot C_{w}+Q_{2}}{m_{3} \cdot Q_{3}} \times 100 \%$

where $m_{2}(\mathrm{~kg})$ is the weight of dry leaves per curing batch in per bulk curing barn, $m_{3}(\mathrm{~kg})$ is the weight of bio-fuel that is consumed, $Q_{2}(\mathrm{~kJ})$ is the heat dissipation of the wall and roof during the entire tobacco curing process, and $Q_{3}(\mathrm{~kJ} /$ $\mathrm{kg}$ ) is the net calorific value of the bio-fuel.

\section{Design and Construction}

An integrated furnace with a heat-dissipating design for the combustion and gasification of bio-fuel (ICBl) was designed according to the combustion characteristics of the bio-fuel, as shown in Fig. 2. The furnace was divided into a solid fuel combustion and gasification area (A), a gasification gas combustion area (B), and a heat exchanger (C). The unit measured $1400(\mathrm{~L}) \times 910(\mathrm{~W}) \times 1850(\mathrm{H}) \mathrm{mm}$. An automatic temperature control instrument was employed to control the bio-fuel combustion and gasification rate.

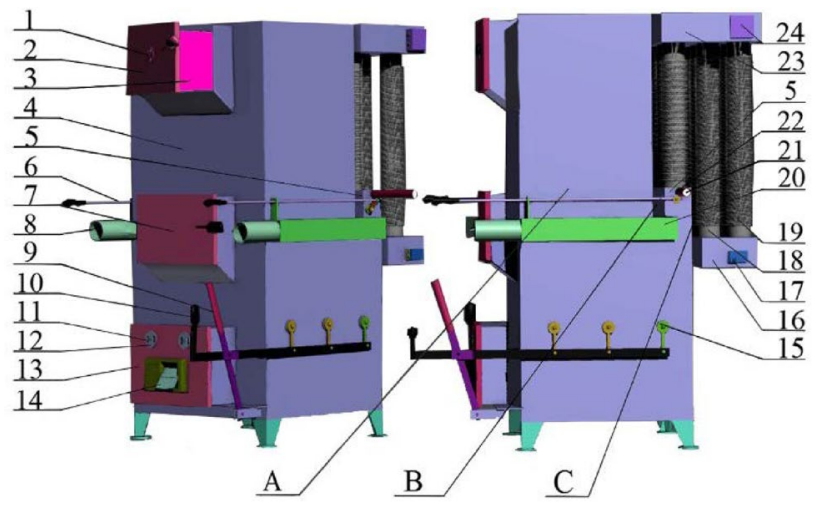

Fig. 2 Design of biomass fuel furnace. (A) Solid fuel combustion and gasification area; (B) Gasification gas combustion area; (C) Heat exchanger. (1) Observation hole, (2) Upper fuelling door, (3) Upper bio-fuel inlet, (4) Furnace body, (5) Gas combustor, (6) Pull rod for controlling fire, (7) Lower fuelling door, (8) Combustion air inlet, (9) Handle for removing large amounts of ash, (10) Handle for removing small amounts of ash, (11) Rotary air inlet cover plate, (12) Hole for air inlet, (13) Ash unloading door, (14) Electronic air intake gate, (15) Bearing for ash cleaning. (16) Lower box, (17) Exchanger cleaning gate, (18) Flue pipe, (19) Radiating aluminum fin, (20) Combustion air inlet duct, (21) Observation hole for gasification gas combustion, (22) Observation pipe for gasification gas combustion, (23) Upper box, (24) Smoke outlet to interface

The provision of bio-fuel, the burning of that fuel, and the production of gasification gas occur in the solid fuel combustion and gasification area, which primarily consists of inlets for filling square or rod-type bio-fuels ((3), (7)), the furnace body (4), air intakes ((11), (14)), and ash removal devices ((9), (10), (13), and (15)). The solid bio-fuel is completely combusted, producing large amounts of combustible gas and tar. To control the solid bio-fuel combustion and gasification, an automatic control instrument regulates the size of the opening of the electronic air intake gate (14), based on the heat requirements for tobacco curing. When the amount of air being drawn through the electronic air intake gate (14) into the furnace is a maximum but still does not satisfy the requirements for curing, the rotary air inlet cover plate (11) can be opened manually on the hole for air inlet (12) to allow air entering.

The gasification gas combustion area is located in the center of the ICBl (Fig. 3). There is a gasification gas burner (5-3), a pressure fire board (5-2), passage ways for the combustion-helping air ((8), (20), (5-5), (5-6), and (5-4)), and points at which it is possible to observe the combustion of the gasification gas $(21,22)$. In this part of the furnace, the gasification gas produced by the combustion of the solid fuel is burned. When the high-temperature gasification gas comes into contact with the external high-temperature combustion air that is being fed through a preheating channel (5-6) and into the high-temperature region of the solid fuel combustion and gasification area, it spontaneously ignites. 


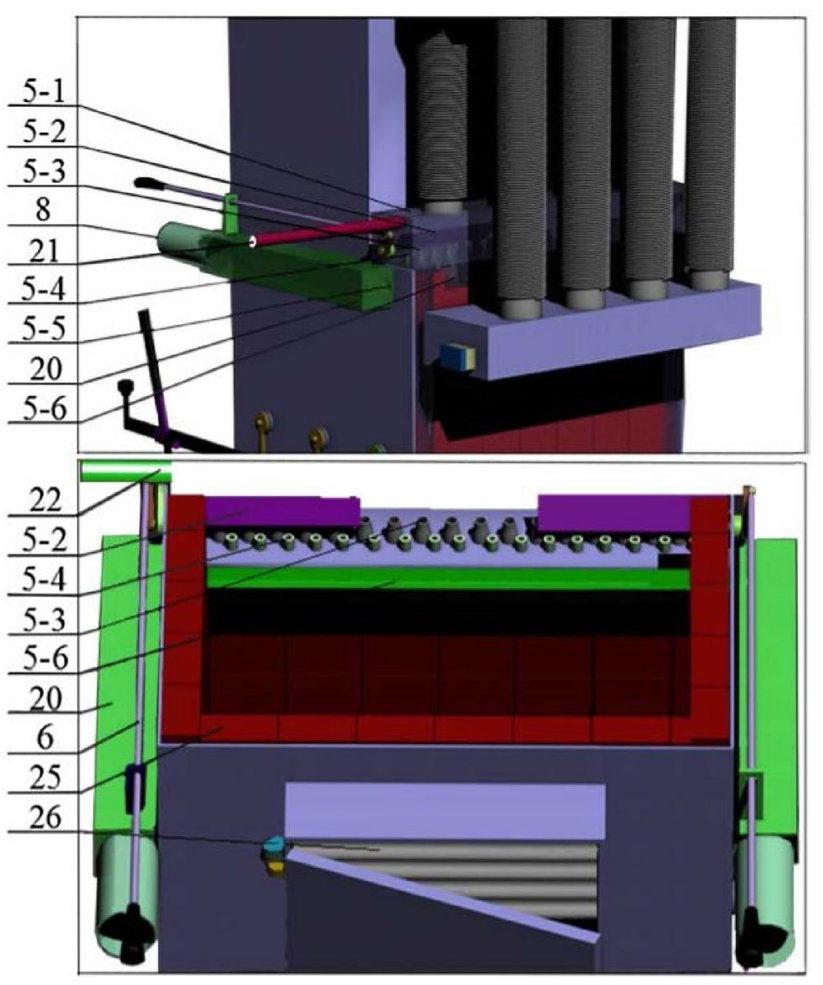

Fig. 3 Partition of gas combustor. Above: right side; Below: front looking down. (5-1) Outer wall of ICBl gas combustion section, (5-2) Pressure fire board, (5-3) Gasification gas burner, (5-4) Combustion air outlet, (5-5) Inner combustion air inlet, (5-6) Combustion air preheating channel, (25) Refractory furnace lining, (26) Furnace grate

The gasification gas flames are controlled as follows: when less heat is required for the curing process, the number of gas burners (5-3) is adjusted with both ends of the pull rod for controlling fire (6), which is connected to the rotating pressure fireboard (5-2), such that the size of the flames can be controlled.

The heat exchanger is the primary heat dissipation structure in the ICBl. It has a box-like body ((4), (16), and (23)) with flue pipes and their accessories ((18), (19)). It also incorporates the outer wall of the ICBl solid fuel combustion and gasification area. The flue pipe layout is vertical with respect to the ground, to increase the residence time of the hot air produced during the combustion of the solid fuel and gasification gas and thus be conducive to heat dissipation.

\section{Materials and Dimensions}

To prevent corrosion and prolong the service life of the ICBl, acid-resistant steel (GB/T711-1988, China) was used to fabricate the main components. According to the predicted furnace temperatures and heat exchanger distribution, as determined using Eqs. (2)-(4), steel plate and tube with a thickness of 3 or $4 \mathrm{~mm}$ was selected (Table 1). Cast iron capable of withstanding high temperatures was adopted to fabricate the furnace grate and gasification gas burner. The refractory furnace lining was formed from blocks measuring $120(\mathrm{~L}) \times 60(\mathrm{~T}) \times 500(\mathrm{H}) \mathrm{mm}$. After assembly, the outer surfaces of the ICB1 were treated with a high-temperature coating. To minimize the frequency at which the furnace must be refueled, the fuel load was maximized. The combustion of this fuel can be regulated during the tobacco curing process. A market quotation placed the projected sale price of the ICB1 at $\$ 1454.54$, which is higher than that of established coal-fired heating equipment (\$1181.82).

\section{Experimental Design}

Experiments were carried out from July-September of 2013-2015 in Luonan County in Shaanxi Province, Furong town in Hunan Province, and Shizhu County in Chongqing City, China. A bulk curing barn with descending air was selected for the tests because this type of barn is more common in those tobacco planting areas that use flue-curing (Fig. 1). The walls were approximately $240 \mathrm{~mm}$ thick and constructed using baked bricks.

Tobacco stalks were broken into pieces and processed into BBF. Firewood from Acer davidii Franch was broken into fragments, measuring $8-10 \mathrm{~cm}$ in length, which were fed into the fuel inlet of the furnace. The different
Table 1 Dimensions and thickness of main components (See also Fig. 2)

\begin{tabular}{llll}
\hline Assembly & Components & Dimensions (mm) & $\begin{array}{l}\text { Material } \\
\text { thickness } \\
(\mathrm{mm})\end{array}$ \\
\hline Part A & Upper part & $850 \times 910 \times 800$ & 4 \\
& Lower part & $1050 \times 910 \times 1050$ & 4 \\
Part B & Combustion air inlet duct & $140 \times 950 \times 140$ & 3 \\
& Outer wall of ICBl gas combustion & $150 \times 910 \times 200$ & 4 \\
& section & $133 \times 700$ or $133 \times 1100$ & 3 or 4 \\
Part C & Flue pipe & $500 \times 910 \times 150$ & 3 \\
& Upper box & $320 \times 910 \times 150$ & 3 \\
\hline
\end{tabular}

Dimensions are given as length $\times$ width $\times$ height or diameter $\times$ length 
experimental conditions are described in Table 2. In the loading chamber of the barn, for each batch, mature middle tobacco leaves of a uniform quality were picked and hung using clips. The error in the weight of the 5000-kg load of green tobacco was within $\pm 50 \mathrm{~kg}$.

\section{Measurement Methods}

\section{Temperature Changes in ICBI Longitudinal Section}

Given the heat conduction characteristics, it is known that the temperature distribution in the ICBl is continuous. Therefore, the temperature changes on the right side of the ICBl can be regarded as being indicative of that in the longitudinal section. The ICBl units were located in an open, windless space. To observe the temperature changes, a Kriging interpolation map was generated for different temperatures using ArcGIS 10.0 [23]. To analyze error estimates, grid points on the right side of the ICBl, $15 \mathrm{~cm}$ apart, were inspected regularly. An infrared temperature-measuring instrument (Wo high HGK350, China) was employed to measure the temperature at the sampling points when the bio-fuel was burning steadily.

\section{Gas Emission from Chimney}

At the key DBTs of 38,48 , and $68^{\circ} \mathrm{C}$ during test 1 , a flue gas analyzer (Ecom-J2KN, Germany) was employed to detect the gas temperature (GT), as well as the oxygen $\left(\mathrm{O}_{2}\right)$, carbon monoxide $(\mathrm{CO})$, carbon dioxide $\left(\mathrm{CO}_{2}\right)$, nitric oxide (NO), nitrogen dioxide $\left(\mathrm{NO}_{2}\right)$, and sulfur dioxide $\left(\mathrm{SO}_{2}\right)$ concentrations at the chimney exit, while the fuel was burning steadily during tobacco curing process.

\section{Comparison of System Thermal Efficiency and Curing Energy Consumption}

Fuel and electricity consumption were recorded during the experiments. The quality of the green and dried tobacco, for each batch and barn, was analyzed statistically by taking representative samples. The operating costs for the tobacco curing were equal to the local labor cost per unit time multiplied by the number of people required to fuel the furnace and remove the ash. The system thermal efficiency was calculated using Eq. (5).

\section{Results and Discussion}

\section{Spatial Temperature Distribution in ICBI Longitudinal Section}

The spatial temperature distribution when the bio-fuel was burning steadily is shown in Fig. 4. Two regions exhibited the highest temperatures, specifically, in the solid fuel combustion and gasification gas combustion areas. In the transition region between the two regions having the highest temperature, the second-highest temperature was observed, which may be affected by the heating of the combustion air in the preheating channel. The group of flue pipes near the gasification gas burner led to there being a high temperature in this area. Therefore, the material and welding of these pipes should be strictly regulated.

To reduce the weight of the equipment and increase the heat dissipation, the refractory lining materials above the lower bio-fuel filling inlet (7), where the temperature is low, can be relatively thin. Without fans to force the convection in the heat exchanger, the temperature between the smoke outlet and the interface (24) was approximately $220^{\circ} \mathrm{C}$, indicating that the ICB1 has a good heat-dissipation effect.

The market for dehydrated vegetables and fruits is important in many countries around the world [24]. Given the range of sorption isotherms of various foods [25], the drying capacity of the ICBl, designed in the present study, is such that it could be applied to the drying of agricultural and fisheries products in areas with rich biomass resources, while its scale could be adjusted according to the production volume.

\section{Variation in Gas Emissions from Chimney}

The primary tail gas composition and quantitative analysis of the key DBT points during tobacco curing are listed in Table 3, assuming steady burning of the bio-fuel. The differences in the GT, as well as the $\mathrm{O}_{2}$ and $\mathrm{CO}$ concentrations, can be clearly seen. The $\mathrm{CO}$ is a product of the incomplete combustion of hydrocarbons. For the same fuel, the $\mathrm{CO}$ concentration in barn $\mathrm{A}$, that is, $0.8-1.7 \%$, is considerably
Table 2 Summary of fuel types and combustion modes

\begin{tabular}{llllll}
\hline & Location & Treatments & Heat exchanger & Fuel type & Combustion mode \\
\hline Test 1 & Luonan; & Barn A & ICBl & BBF & Secondary combustion \\
& Furong & Barn B & Coal furnace & BBF & Direct combustion \\
& & Barn C & Coal furnace & Coal-fuel & Direct combustion \\
Test 2 & Shizhu & Barn D & ICBl & Firewood & Secondary combustion \\
& & Barn E & Coal furnace & Firewood & Direct combustion \\
\hline
\end{tabular}




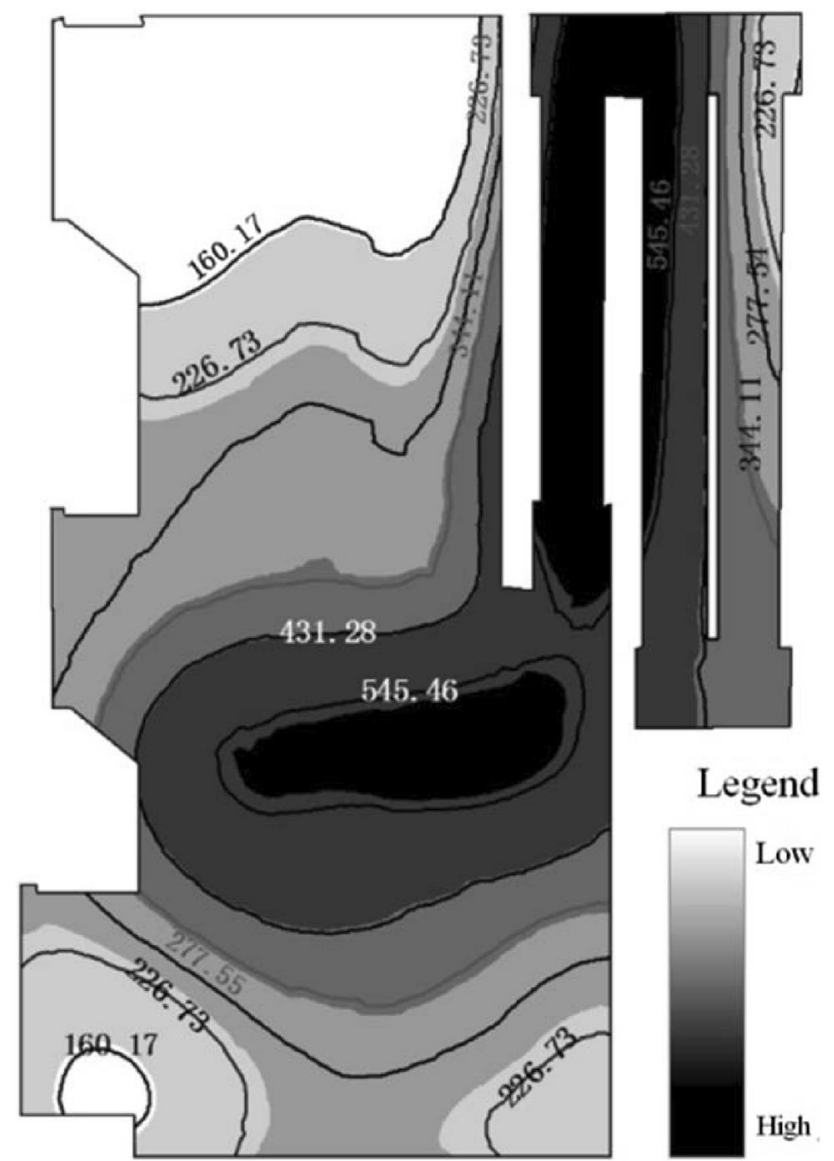

Fig. 4 Temperature distribution on right side of ICB1

lower than that in barn $\mathrm{B}$, pointing to the fact that the $\mathrm{BBF}$ combustion is more complete in the ICBI. The GT in barn A is lower than that in barns B and C, which can be explained by the fact that more heat is dissipated in barn $\mathrm{A}$, while the location of the furnace body and the exchanger, as well as the layout of the flue pipes in barn A, are more conducive to heat loss.
It is well known that $\mathrm{NO}, \mathrm{NO}_{2}$, and $\mathrm{SO}_{2}$ gases are internationally categorized as primary atmospheric pollutants. The $\mathrm{NO}, \mathrm{NO}_{2}$, and $\mathrm{SO}_{2}$ concentrations at the chimney exit of barn A were well below the limits specified in China's Gas Pollutant Emission Standards (GB 16,297-1996). However, the $\mathrm{SO}_{2}$ concentration of barn $\mathrm{C}$ was more than 1500 $\mathrm{mg} \mathrm{m}^{-3}$, which exceeds the maximum human exposure limit over $8 \mathrm{~h}$ [26].

\section{Comparison of Energy Consumption and System Thermal Efficiency}

Table 4 lists the results of test 1 and test 2 . For the same amount of green tobacco, and assuming the use of the same loading pattern (test 1), the cost of tobacco curing was lowest in the case of barn A, followed by barn C, with Barn B being the most costly. For test 2 , in which firewood was used as the fuel, the cost of curing was lower for barn D than for barn E. Even though the same bio-fuel was used for curing in test 1 and test 2 , the use of a different furnace/combustor resulted in a considerable difference in the fuel consumption. The combustion mechanism of bio-fuels, which is divided in four stages, differs from that for coal [27]. Thus, it was concluded that, during the direct combustion of bio-fuel to provide the heat needed to cure tobacco, a large amount of gasification gas and tar with a low calorific value were discharged from the chimneys, thus resulting in fuel wastage.

Regarding the use of different types of bio-fuels in a given furnace, the maximum fuel loading and fire-keeping times for barns $\mathrm{A}$ and $\mathrm{D}$ were greater than those for barns $\mathrm{B}$ and $\mathrm{E}$, respectively. In addition, the burning of fuels in barns $\mathrm{A}$ and $\mathrm{D}$ was controlled during the experiments by the automatic control system, according to the amount of heat required to cure the tobacco, with a greater amount of fuel and a longer fire-keeping time reducing the refueling frequency and operating costs for tobacco curing.

The system thermal efficiencies of barns A and D were 55.26 and $53.17 \%$, respectively, which were higher than

Table 3 Components and quantity of main gas emissions at chimney exit at key DBTs of tobacco curing

\begin{tabular}{lllllllll}
\hline & $\begin{array}{l}\mathrm{DBT} \\
\left({ }^{\circ} \mathrm{C}\right)\end{array}$ & \multicolumn{1}{l}{$\mathrm{GT}\left({ }^{\circ} \mathrm{C}\right)$} & \multicolumn{1}{l}{$\mathrm{O}_{2}(\%)$} & $\mathrm{CO}(\%)$ & $\mathrm{CO}_{2}(\%)$ & $\mathrm{NO}\left(\mathrm{mg} \mathrm{m}^{-3}\right)$ & $\mathrm{NO}_{2}\left(\mathrm{mg} \mathrm{m}^{-3}\right)$ & $\mathrm{SO}_{2}\left(\mathrm{mg} \mathrm{m}^{-3}\right)$ \\
\hline Barn A & 38 & $98.6 \pm 2.8$ & $10.5 \pm 0.6$ & $1.7 \pm 0.3$ & $8.8 \pm 0.6$ & $5.4 \pm 0.9$ & $0.4 \pm 0.03$ & $463.2 \pm 42.5$ \\
& 48 & $138.5 \pm 3.2$ & $11.3 \pm 0.3$ & $1.6 \pm 0.2$ & $5.6 \pm 0.4$ & $4.2 \pm 1.3$ & $0.3 \pm 0.02$ & $417.2 \pm 38.9$ \\
& 68 & $160.1 \pm 5.6$ & $12.6 \pm 0.6$ & $0.8 \pm 0.3$ & $4.7 \pm 0.2$ & $3.8 \pm 0.9$ & $0.3 \pm 0.02$ & $401.2 \pm 39.0$ \\
Barn B & 38 & $106.7 \pm 3.2$ & $13.5 \pm 0.6$ & $6.5 \pm 0.7$ & $6.2 \pm 0.7$ & $15.9 \pm 1.2$ & $1.4 \pm 0.08$ & $561.5 \pm 41.9$ \\
& 48 & $185.1 \pm 5.8$ & $16.6 \pm 0.8$ & $7.6 \pm 0.8$ & $4.2 \pm 0.3$ & $14.6 \pm 1.4$ & $1.3 \pm 0.1$ & $603.2 \pm 38.4$ \\
& 68 & $180.4 \pm 6.1$ & $17.7 \pm 0.9$ & $5.2 \pm 0.5$ & $3.6 \pm 0.3$ & $13.2 \pm 1.2$ & $1.2 \pm 1.1$ & $634.1 \pm 42.1$ \\
Barn C & 38 & $110.2 \pm 3.4$ & $13.6 \pm 0.4$ & $8.4 \pm 1.3$ & $5.9 \pm 0.4$ & $23.2 \pm 7.2$ & $13.1 \pm 1.8$ & $1691.9 \pm 140.6$ \\
& 48 & $172.2 \pm 5.9$ & $15.9 \pm 0.4$ & $8.8 \pm 1.3$ & $4.0 \pm 0.5$ & $22.2 \pm 7.3$ & $12.4 \pm 2.9$ & $1586.9 \pm 128.7$ \\
& 68 & $193.2 \pm 6.3$ & $16.7 \pm 0.5$ & $6.3 \pm 1.3$ & $3.9 \pm 0.4$ & $20.2 \pm 5.4$ & $10.2 \pm 3.1$ & $1342.8 \pm 117.5$ \\
\hline
\end{tabular}


Table 4 Cost of tobacco curing and system thermal efficiency

\begin{tabular}{|c|c|c|c|c|c|}
\hline & \multicolumn{3}{|l|}{ Test 1} & \multicolumn{2}{|l|}{ Test 2} \\
\hline & Barn A & Barn B & Barn C & Barn D & Barn E \\
\hline Curing time (h) & 126 & 130 & 131 & 121 & 127 \\
\hline Maximum fuel loading (kg) & 150 & 50 & 60 & 130 & 45 \\
\hline Maximum fire-keeping time (h) & 36 & 6 & 8 & 32 & 5.5 \\
\hline Loading green tobacco (clips) & 420 & 420 & 420 & 456 & 456 \\
\hline Green tobacco quality per batch per barn $(\mathrm{kg})$ & 4218 & 4208 & 4191 & 4195 & 4203 \\
\hline Dry tobacco quality per batch per barn $(\mathrm{kg})$ & 692 & 688 & 683 & 698 & 693 \\
\hline Operating cost for tobacco curing $(\mathbf{\$})$ & 17.78 & 44.44 & 29.63 & 14.81 & 38.52 \\
\hline Power consumption (kWh) & 148 & 149 & 150 & 152 & 155 \\
\hline Fuel consumption $(\mathrm{kg})$ & 985 & 1467 & 1023 & 1368 & 1760 \\
\hline Total cost (\$ per barn per batch) & 112.28 & 178.32 & 90.11 & 120.65 & 170.77 \\
\hline Curing cost per kg dry tobacco $(\$ / \mathrm{kg})$ & 0.16 & 0.26 & 0.23 & 0.17 & 0.25 \\
\hline System thermal efficiency (\%) & 55.26 & 37.04 & 49.52 & 53.17 & 41.48 \\
\hline
\end{tabular}

According to local market prices in 2015, coal was $\$ 56.29(\mathrm{t})$, BBF was $\$ 66.66(\mathrm{t})$, firewood was $\$ 81.48(\mathrm{t})$ and electricity was $\$ 0.10(\mathrm{kWh})$
Table 5 Lignin, cellulose, and hemicellulose contents of biomass fuels

\begin{tabular}{lllll}
\hline & Lignin (\%) & Cellulose (\%) & $\begin{array}{l}\text { Hemicel- } \\
\text { lulose } \\
(\%)\end{array}$ & $\begin{array}{l}\text { Calorific } \\
\text { value (MJ/ } \\
\mathrm{kg})\end{array}$ \\
\hline $\begin{array}{c}\text { Biomass bri- } \\
\text { quette fuel } \\
\text { (Tobacco stems) }\end{array}$ & 20.77 & 36.92 & 29.52 & 17.23 \\
$\begin{array}{l}\text { Firewood } \\
\text { Acer davidii } \\
\text { Franch) }\end{array}$ & 16.49 & 44.69 & 26.16 & 17.99 \\
\hline
\end{tabular}

those of the other three fuel-controlled barns, as reported by Kadete [28]. This showed that the bio-fuels offered a superior combustion efficiency.

Table 5 lists the lignin, cellulose, and hemicellulose contents of different biomass fuels. The morphological characteristics of harvested tobacco stalks with abundant holocellulose and alpha-cellulose are similar to those of non-woods and hardwoods [29, 30], making them a better raw material for the production of biomass fuels [20,31]. The statistics state that a three-hectare field of tobacco stalks could cure one hectare of tobacco leaves. It therefore makes good sense to process tobacco stalks into BBF for use in tobacco curing.

The shapes and sizes of the bio-fuels used in China vary with the tobacco-growing area [8]. Pambudi et al. [32] and $\mathrm{Lu}$ et al. [33] found that the surface area per unit mass, as well as the diameter of biomass briquette, affects the reaction time and combustion GT. This experimental result was obtained with a rod biomass fuel that was $32 \mathrm{~mm}$ in diameter and approximately $50 \mathrm{~mm}$ in length. Further research is required to determine the most suitable shape and size of the biomass fuels used for curing tobacco.

\section{Conclusions}

In the present study, a special integrated furnace with a heat dissipating structure for the combustion and gasification of bio-fuels for tobacco curing was designed and tested. The furnace is compact, simple to install, and convenient to operate. The experimental results indicated that the combustion of bio-fuels produced sufficient heat and generated less than $1.7 \%$ carbon monoxide, which was lower than that produced by controlled direct combustion. The integrated furnace increased the system thermal efficiency of the barn, which reached 53.17-55.26\%. The large-capacity chamber of the designed furnace structure combined with the automatic temperature control instrument improved the maximum fuel loading and fire-keeping time of the furnace. Therefore, thus, the refueling frequency and operating costs were reduced. Thus, this furnace is suitable for tobacco curing in those areas using flue-curing, and could also be applied to the commercial drying of agricultural products.

Acknowledgements This research was funded by a strategic cooperation program between Henan Agricultural University and the Bijie Tobacco Company [BJ2014006], Henan Provincial Tobacco Company [SWZ001]. The authors would like to thank the equipment sponsor Yuzhou Fangzheng and XuChang TongXing Combustion Furnace Co., Ltd., China. We would like to thank Editage [http://www.editage.cn] for English language editing.

Open Access This article is distributed under the terms of the Creative Commons Attribution 4.0 International License (http://creativeco mmons.org/licenses/by/4.0/), which permits unrestricted use, distribution, and reproduction in any medium, provided you give appropriate credit to the original author(s) and the source, provide a link to the Creative Commons license, and indicate if changes were made. 


\section{References}

1. Campbell, J.S.: Tobacco and the environment: the continuous reduction of worldwide energy source use for green leaf curing. Beiträge zur Tabakforschung (Contrib. Tob. Res.) 16(3), 107-117 (1995)

2. Wang, J.A., Song, Z.P., Wei, Y.W., Yang, G.H.: Combination of waste-heat-recovery heat pump and auxiliary solar-energy heat supply priority for tobacco curing. Appl. Ecol. Environ. Res. 15(4), 1871-1882 (2017)

3. Zhang, J.J., Smith, K.R.: Household air pollution from coal and biomass fuels in China: measurements, health impacts, and interventions. Environ. Health Perspect. 115(6), 848-855 (2007)

4. Chen, L., Xing, L., Han, L.: Renewable energy from agro-residues in China: solid biofuels and biomass briquetting technology. Renew. Sustain. Energy Rev. 13(9), 2689-2695 (2009)

5. Tippayawong, N., Tantakitti, C., Thavornun, S.: Investigation of lignite and firewood co-combustion in a furnace for tobacco curing application. Am. J. Appl. Sci. 3(3), 1775-1780 (2006)

6. Roy, M.M., Corscadden, K.W.: An experimental study of combustion and emissions of biomass briquettes in a domestic wood stove. Appl. Energy 99, 206-212 (2012)

7. International Energy Agency (IEA): World Energy Outlook 2007: China and India Insights. IEA, Paris (2007)

8. Ren, T.B.: Application of Biomass Moulding Fuel to Flue-Cured Tobacco Furnaces: Efficiency and Cost Effectiveness. Coresta, Hilton (2016)

9. Promdee, K., Chanvidhwatanakit, J., Satitkune, S., Boonmee, C., Kawichai, T., Jarernprasert, S., Vitidsant, T.: Characterization of carbon materials and differences from activated carbon particle(ACP) and coal briquettes product (CBP) derived from coconut shell via rotary kiln. Renew. Sustain. Energy Rev. 75, 1175-1186 (2017)

10. Cakir, N., Alp, E., Yetis, U.: Evaluation of environmental performance based on proximity to bat associated resource utilization and emission values: a case study in a steel-making industry. Waste Biomass Valorization 7(4), 975-993 (2016)

11. Kong, H.W.: Current Status of Biomass Utilization in Malaysia, pp. 1-15. Forest Research Institute Malaysia, Kuala Lumpur (2000)

12. Wang, X.F., Xu, G.Z., Zhang, B.L., Jiao, Y.Z., Lu, H.F., Li, B.M.: Application of tobacco stems briquetting in tobacco flue-curing in rural area of China. Int. J. Agric. Biol. Eng. 8(6), 84-88 (2015)

13. Siddiqui, K.M., Rajabu, H.: Energy efficiency in current tobaccocuring practice in Tanzania and its consequences. Energy 21(2), 141-145 (1996)

14. Liu, S.Y.: Development and test study on biomass briquettes combustion equipment. Ph.D. Thesis, Henan Agricultural University, China: (2003)

15. Bach, Q.V., Tran, K.Q., Skreiberg, Ø: Hydrothermal pretreatment of fresh forest residues: effects of feedstock pre-drying. Biomass Bioenergy 85, 76-83 (2016)

16. Xiang, Y., Zhang, Z., Li, H., Sun, Q., Teng, Z., Li, Z., Jiang, J.: Application of baking equipment of hydrocarbon organic matter fuel in bulk curing barn. Trans. Chin. Soci. Agric. Eng. 30(2), 219-223 (2014)

17. Zhang, B., Yang, S., Yang, Q., Zhao, T., Li, G., He, H.: Study on tobacco curing system by biomass pyrolysis gas. Acta Energiae Solaris Sinica 24(5), 683-687 (2002)

18. Siddiqui, K.M.: Analysis of a Malakisi barn used for tobacco curing in East and Southern Africa. Energy Convers. Manag. 42(4), 483-490 (2001)

19. Tippayawong, N., Tantakitti, C., Thavornun, S.: Energy and emission based performance of an experimental tobacco bulk-curing barn. Chiang Mai Univ. J. 3(1), 43-52 (2004)

20. Xiao, X.D., Li, C.M., Ya, P., He, J., He, Y.S., Bi, X.T.: Industrial experiments of biomass briquettes as fuels for bulk curing barns. Int. J. Green Energy 12(11), 1061-1065 (2015)

21. Technical specification for bulk curing barn China:Construction Standard for Bulk Curing Barn. Chinese National Tobacco Corporation.http://www.doc88.com/p-03044266920.html (2009)

22. Akehurst, B.C.: Tobacco. Humanities Press, New York (1981)

23. Wu, T., Li, Y.: Spatial interpolation of temperature in the United States using residual kriging. Appl. Geogr. 44, 112-120 (2013)

24. Funebo, T., Ahrne, L., Prothon, F., Kidman, S., Langton, M., Skjoldebrand, C.: Microwave and convective dehydration of ethanol treated and frozen apple-physical properties and drying kinetics. Int. J. Food Sci. Technol. 37, 603-614 (2002)

25. Mujumdar, A.S. (ed.): Handbook of Industrial Drying, p. 16. CRC Press, Florida (2014)

26. OSHA (Occupational Safety and Health Administration): Occupational Exposure Standards. United States Department of Labor, Washington (1972)

27. Nussbaumer, T.: Combustion and co-combustion of biomass: fundamentals, technologies, and primary measures for emission reduction. Energy Fuels 17(6), 1510-1521 (2003)

28. Kadete, H.: Energy conservation in tobacco curing. Energy 14(7), 415-420 (1989)

29. Shakhes, J., Marandi, M.A., Zeinaly, F., Saraian, A., Saghafi, T.: Tobacco residuals as promising lignocellulosic materials for pulp and paper industry. BioResources 6(4), 4481-4493 (2011)

30. Kulić, G.J., Radojičić, V.B.: Analysis of cellulose content in stalks and leaves of large leaf tobacco. J. Agric. Sci. Belgrade 56(3), 207-215 (2011)

31. Nanda, S., Dalai, A.K., Berruti, F., Kozinski, J.A.: Biochar as an exceptional bioresource for energy, agronomy, carbon sequestration,activated carbon and specialty materials. Waste Biomass Valorization 7(2), 201-235 (2016)

32. Pambudi, N.A., Torii, S., Saptoadi, H., Sumbodo, W., Syamsiro, M., Surono, U.B.: Experimental study on combustion of biobriquettes Jatropha curcassolid waste. J. Environ. Eng. Manag. 20(2), 133-136 (2010)

33. Lu, H., Ip, E., Scott, J., Foster, P., Vickers, M., Baxter, L.L. Effects of particle shape and size on devolatilization of biomass particle. Fuel 89(5), 1156-1168 (2010) 